\title{
The investment priorities of stakeholders in forest protection and development in Vietnam from 2011-2019
}

\author{
Pham Thu Thuy, Dao Thi Linh Chi, Hoang Tuan Long, Ngo Ha Chau, Hoang Thi Uyen, Tran Ngoc
} My Hoa, Hoang Minh Hieu, and Nguyen Van Dien

\section{Key messages}

- This policy brief shows the investment priorities of stakeholders in forest protection and development from 2011-2019, focusing on 16 key areas: 1. forest conservation; 2. enhancement of forest carbon stocks (forest restoration/regeneration); 3. sustainable logging practices (RIL; forest certification); 4. afforestation and reforestation; 5. agricultural land use emission reductions (low emission agriculture/greening business practices, e.g. zero deforestation supply chains); 6 . design of national level REDD+ strategies policies and programs; 7. design of sub-national level REDD+ strategies, policies and programs; 8. national level implementation of REDD+ strategy, policies and programs (e.g. MRV or safeguards institutions); 9. implementation of REDD+ site activities (including demonstration sites); 10. tenure rights (land, trees); 11. biodiversity conservation; 12. poverty alleviation; 13. forest governance (illegal logging, rule of law, corruption); 14. community-based or joint forest management (as co-benefit of REDD); 15. adaptation to climate change; and 16. REDD+ related carbon finance/ trading. Stakeholder investment priorities for these 16 areas mostly expanded throughout these years to keep up with worldwide forestry sector development trends. Favorable support from stakeholders can create advantageous conditions for Vietnam to experiment with and pioneer many policy areas and new technologies.

- Areas such as poverty alleviation, forest governance, biodiversity conservation, agricultural land use emission reductions, and sustainable logging practices, as well as REDD+ design and implementation have attracted the greatest attention from stakeholders. Issues of tenure rights and sustainable logging practices, despite limited increases in priority, remain key investment priorities of the organizations surveyed. Stakeholder prioritization of and investment in afforestation and reforestation have decreased over time.

- Although the prioritization of financial and technological support during the period from 2011-2019 has created favorable conditions for developing the forestry sector, stakeholders' current priorities also show that many areas (e.g. communitybased forest management, carbon finance/trading, forest product processing) remain underdeveloped and their investment potential and roles have not been met.

- The aims of the Forest Law are to develop a comprehensive forestry sector, a chain of management, protection, development, forest use, and forest product trade. However, stakeholders' areas of interest and priorities have so far focused mainly on forest management and protection. Comprehensive and sustainable forestry sector development requires investment prioritization for all stages.

- As each stakeholder requires different investment priorities, understanding these can not only help the Government to use resources more efficiently and avoid duplication, but also create more effective strategies for mobilizing capital for the forestry sector.

\section{Introduction}

The forestry sector plays an important role in contributing to Vietnam's economic and social development as well as to climate change mitigation and adaptation. The forestry sector's development potential is highly significant, but one of its difficulties is ensuring sufficient financial resources for the implementation of sustainable and effective forest protection and development. Financial and technical support from international organizations, donors, the private sector, and domestic and international NGOs have always played an essential role in providing and supplementing resources for Vietnam to implement policies and meet its international commitments. 
However, knowledge and analyses of different forestry sector stakeholders' priority and investment trends have been lacking until now, as has a comprehensive picture of the sector's opportunities and challenges. This policy brief aims to address such gaps by answering three key questions:

- What were the investment interests of stakeholders in general, and international organizations and donors in particular, for Vietnam's forestry sector during the 2011-2019 period?

- Which areas still lack funding from stakeholders to support Vietnam's forestry sector development?

- What are the opportunities and challenges for stakeholders in providing financial and technical support to implement forest protection and development in Vietnam?

This policy brief is based on research results from the Global Comprehensive Study on REDD+ (GCSREDD+) project, conducted by CIFOR and funded by NORAD from 2009-2020. This study collected data on stakeholders' investment priorities in Vietnam from 2011-2019, as well as opportunities and challenges for the implementation of forest protection and development in the country. We conducted research and collected data three times during the 2011-2019 period: from 2011-2012; 2015-2016; and 2018-2019 to analyze relevant stakeholders' investment priority trends. Based on secondary data, interviews with expert groups, and consultation workshops, the research team identified and interviewed 52 organizations from 2011-2012, 51 organizations from 2015-2016, and 28 organizations from 2018-2019 that have offered important financial and technical support for forestry sector development in Vietnam. These organizations were categorized in five main groups: donors (foreign government agencies and intergovernmental organizations); national and international business organizations; domestic and international nongovernmental organizations; government agencies; and national and international research institutes. The number of organizations surveyed from 2018-2019 (28 organizations) fell sharply compared to the previous periods (52 from 2011-2012, and 51 from 2015-2016) because many international organizations, NGOs and donors that were active in Vietnam in 2011-2012 are no longer operating in the forestry sector. Consequently, despite fewer organizations being surveyed in 20182019 , the research results still represent a factual and comprehensive picture of the interests of and investments made by stakeholders currently operating in Vietnam.

\section{Stakeholder investment priorities and sectors of interest}

Study results show the investment priorities of stakeholders in forest protection and development from 2011-2019, focusing on 16 key areas: 1 . forest conservation; 2 . enhancement of forest carbon stocks (forest restoration/regeneration); 3. sustainable logging practices (RIL; forest certification); 4. afforestation and reforestation; 5 . agricultural land use emission reductions (low emission agriculture/greening business practices, e.g. zero deforestation supply chains); 6 . design of national level REDD+ strategies policies and programs; 7 . design of sub-national level REDD+ strategies, policies and programs; 8 . national level implementation of REDD+ strategy, policies and programs (e.g. MRV or safeguards institutions); 9. implementation of REDD+ site activities (including demonstration sites); 10 . tenure rights (land, trees); 11. biodiversity conservation; 12 . poverty alleviation; 13. forest governance (illegal logging, rule of law, corruption); 14. community-based or joint forest management (as co-benefit of REDD); 15. adaptation to climate change; and 16. REDD+ related carbon finance/ trading (see Table 1).

Overall, resources and investment priorities from stakeholders for these 16 sectors have mostly increased and expanded over time to keep pace with forestry sector development trends worldwide. Areas such as poverty alleviation, forest governance, biodiversity conservation, agricultural land use emission reductions, and sustainable logging practices, as well as REDD+ design and implementation have attracted the greatest interest from stakeholders. Issues of tenure rights and sustainable forest extraction, despite witnessing limited increases in interest, remain investment priorities of the majority of key organizations surveyed. Stakeholders' prioritization of and investment in afforestation and reforestation have decreased over time.

Many stakeholders are no longer prioritizing areas that previously accounted for large proportions of total investments in time and budgets. For example, in $2011-2012,55 \%$ of organizations stated that forest conservation accounted for $50-100 \%$ of their total investments and resources, while in 2019 , no organization spent more than $50 \%$ of its time and budget on forest conservation.

Similarly, in 2011-2012, 40\% of organizations interviewed said that they prioritized $50-80 \%$ of their 
Table 1. Priority areas for forestry sector investment and support.

\begin{tabular}{|c|c|c|c|c|}
\hline Priority areas & 2011-2012 & 2015- 2016 & 2018- 2019 & $\begin{array}{l}\text { Difference } \\
\text { between } 2011 \\
\text { and } 2019\end{array}$ \\
\hline 1. Forest conservation & $52 \%$ & $53 \%$ & $66 \%$ & $14 \%$ \\
\hline $\begin{array}{l}\text { 2. Enhancement of forest carbon stocks (forest restoration / } \\
\text { regeneration) }\end{array}$ & $42 \%$ & $37 \%$ & $72 \%$ & $30 \%$ \\
\hline 3. Sustainable logging practices (RIL; forest certification) & $33 \%$ & $39 \%$ & $38 \%$ & $5 \%$ \\
\hline 4. Afforestation and reforestation & $48 \%$ & $45 \%$ & $45 \%$ & $-3 \%$ \\
\hline $\begin{array}{l}\text { 5. Agricultural land use emission reductions (low emission } \\
\text { agriculture/greening business practices, e.g. zero defores- } \\
\text { tation supply chains) }\end{array}$ & $31 \%$ & $31 \%$ & $66 \%$ & $35 \%$ \\
\hline $\begin{array}{l}\text { 6. Design of national level REDD+ strategies, policies and } \\
\text { programs }\end{array}$ & $46 \%$ & $55 \%$ & $59 \%$ & $12 \%$ \\
\hline $\begin{array}{l}\text { 7. Design of sub-national level REDD+ strategies, policies } \\
\text { and programs }\end{array}$ & $58 \%$ & $49 \%$ & $59 \%$ & $1 \%$ \\
\hline $\begin{array}{l}\text { 8. National level implementation of REDD+ strategy, policies } \\
\text { and programs (e.g. MRV or safeguards institutions) }\end{array}$ & $42 \%$ & $37 \%$ & $59 \%$ & $16 \%$ \\
\hline $\begin{array}{l}\text { 9. Implementation of REDD+ site activities (including dem- } \\
\text { onstration sites) }\end{array}$ & $50 \%$ & $49 \%$ & $59 \%$ & $9 \%$ \\
\hline 10. Tenure rights (land, trees) & $52 \%$ & $47 \%$ & $55 \%$ & $3 \%$ \\
\hline 11. Biodiversity conservation & $37 \%$ & $43 \%$ & $72 \%$ & $36 \%$ \\
\hline 12. Poverty alleviation & $13 \%$ & $45 \%$ & $69 \%$ & $56 \%$ \\
\hline 13. Forest governance (illegal logging, rule of law, corruption) & $33 \%$ & $53 \%$ & $79 \%$ & $47 \%$ \\
\hline $\begin{array}{l}\text { 14. Community-based or joint forest management (as co- } \\
\text { benefit of REDD) }\end{array}$ & $37 \%$ & $49 \%$ & $66 \%$ & $29 \%$ \\
\hline 15. Adaptation to climate change & $40 \%$ & $41 \%$ & $69 \%$ & $29 \%$ \\
\hline 16. REDD+ related carbon finance/trading & $29 \%$ & $18 \%$ & $45 \%$ & $16 \%$ \\
\hline
\end{tabular}

resources to carry out afforestation and reforestation, but in 2018-2019, no organization indicated doing so as a priority. The number of organizations allocating more than $50 \%$ of their budgets and time to implement REDD+ pilot activities also decreased from 75\% in 20112012 to only $50 \%$ in $2018-2019$. All of the organizations surveyed in 2015-2016 said they prioritized over 50\% of their budgets and time on carrying out activities relating to carbon finance and trading, whereas no organization spent more than $50 \%$ of its budget and resources on addressing this issue in 2018-2019.

In contrast, in 2011-2012, no organization claimed it was prioritizing more than $50 \%$ of its time and budget on enhancement of forest carbon stocks. However, in 2018-2019, over $50 \%$ of organizations participating in the study said were prioritizing $50-80 \%$ of their time and resources on doing so.
National REDD+ program design and implementation are now afforded the highest priority. In 2011-2012, only 33\% of the organizations surveyed said they were allocating more than $50 \%$ of their financial and human resources on implementing national REDD+ programs. However, this number had increased to $66 \%$ in $2015-2016$, and to $60 \%$ in 2019-2020. The number of organizations allocating more than $50 \%$ of their budgets for tenure rights also grew from $57 \%$ in $2011-2012$ to $100 \%$ in $2019-2020$.

While areas such as poverty alleviation and forest governance have been prioritized continuously over the last 10 years, accounting for more than $50 \%$ of organizations' resources, a number of other areas, such as biodiversity conservation, community-based forestry, and adaptation to climate change, have never received more than $33 \%$ of the total budgets and resources of the organizations surveyed. 
Adaptation to climate change

Community-Based or Joint Forest Management (as co-benefit of REDD)

Forest governance (illegal logging, rule of law, corruption)

Poverty alleviation

Biodiversity conservation

Tenure rights (land, trees)

Implementation of REDD+

Implementation of REDD+ strategy, policies and programs (e.g. MRV or safeguards institutions)

Design of sub-national level REDD+ strategies, policies and programs

Design of national level REDD+ strategies, policies and programs

Agricultural land use emission reductions (low emission agriculture/greening business practices, e.g. zero deforestation. .

Afforestation and reforestation

Sustainable logging practices (RIL; forest certification)

Enhancement of forest carbon stocks (forest restoration /regeneration)

Forest conservation

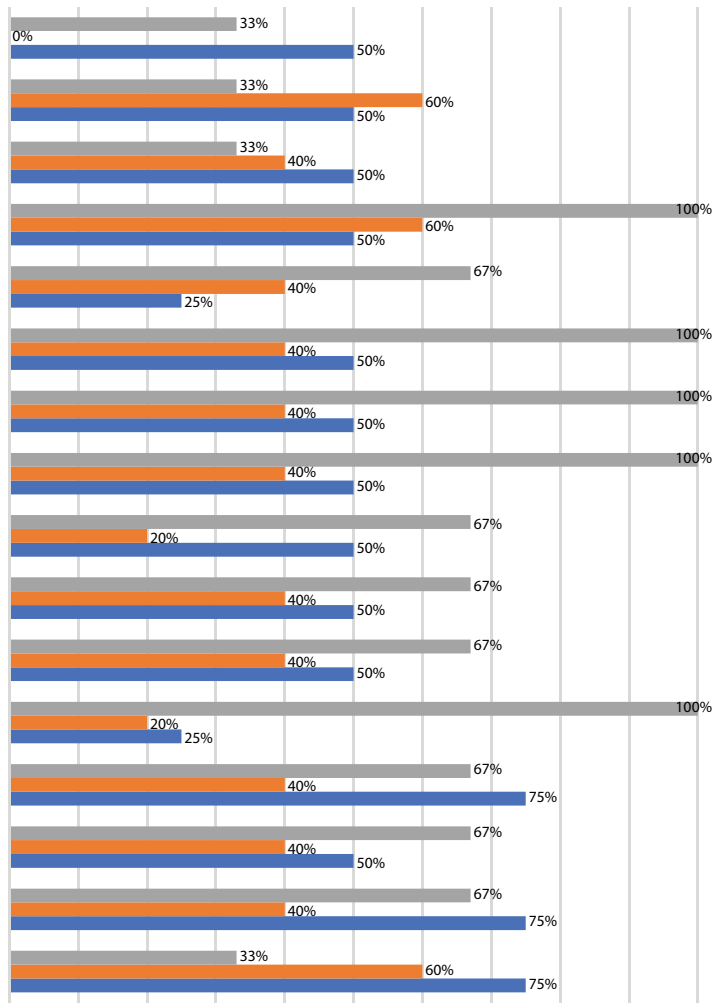

$\begin{array}{lllllllllll}0 \% & 10 \% & 20 \% & 30 \% & 40 \% & 50 \% & 60 \% & 70 \% & 80 \% & 90 \% & 100 \%\end{array}$

$2018-2019(\mathrm{~N}=3)$

$2015-2016(\mathrm{~N}=5)$

$2011-2012(\mathrm{~N}=4)$

Figure 1. Forestry sector priority areas for foreign government agency donors.

Study results also show that different stakeholders have different concerns and investment priorities.

\section{Foreign government agency and intergovernmental organization donors}

Figures 1 and 2 show two investment trends and concerns for donors (including foreign government agencies and intergovernmental organizations) for the Vietnamese forestry sector:

- Priorities and concerns are focused on the following areas: agricultural land use emission reductions; national-level REDD+ strategy, policy and program design; developing measurement and safeguard systems; biodiversity conservation; forest governance; and poverty alleviation. These priorities and concerns are aligned with global forestry development trends as well as requirements from global conventions and policies on climate change, such as the Paris Agreement. Donors are also focusing on supporting policies to limit drivers of deforestation and forest degradation in a comprehensive and more effective way by addressing non-forestry sectors (e.g. agriculture).

- Carbon finance/trading, forest conservation, afforestation and reforestation, and enhancement of forest carbon stocks received less attention and prioritization from donors in 20182019 than in 2011-2012. According to the stakeholders interviewed, reduced priority for these areas is due to concerns over the carbon market not having the potential to grow, and because investment in and financial support for conservation and enhancement of forest carbon stock had been significant during the previous decade.

However, despite foreign government agency donors becoming less concerned with and affording lower priority to community forestry, concern for this area did grow among intergovernmental organizations. Conversely, foreign government agencies are now affording more attention to and investment in tenure rights, while concern for this area has decreased among intergovernmental organization donors. 


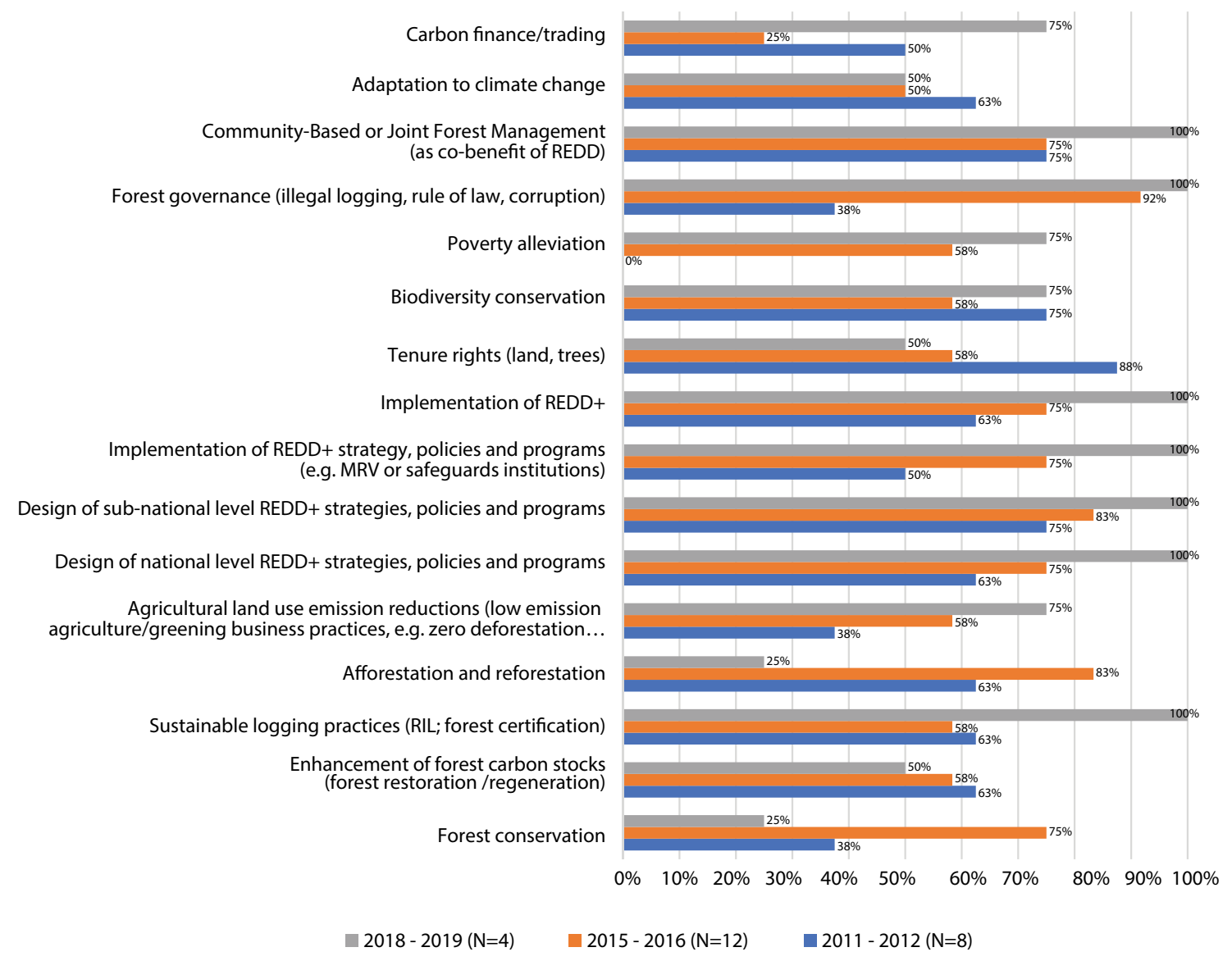

Figure 2. Forestry sector priority areas for intergovernmental organization donors.

\section{National and international business organizations}

Figure 3 below illustrates how the concerns and priorities of national business organizations participating in this research have changed over the years.

In 2011-2012, national business organizations participating in this study focused on conservation, new afforestation and reforestation, and supporting REDD+ pilot projects and programs. During 20152016, they invested most in sustainable forest management certification and reducing emissions from forest land use. By 2018-2019, national business organizations participating in this study prioritized their investments in climate change adaptation, combating illegal logging, and poverty reduction. This change in these priority objectives can be explained by the following reasons: firstly, legal and policy barriers (e.g. unclear land use rights and carbon rights) have made business organizations reluctant to invest in forest protection and development, while they have piloted other potential areas over the last 10 years; and secondly, the pressure for business organizations to implement ecofriendly manufacturing models and incorporate social responsibility is growing, leading to their increased attention to these areas.

The study team encountered many difficulties accessing international business organizations, mainly because these companies are not based in Vietnam, and their information-sharing policies limited their participation in this research. Although there should be more research in future to address this lack of information, the research team's results from a small sample of international business organizations show that their concerns and priorities are broader than those of national business organizations. However, according to these organizations, their main concern is the investment potential of the Vietnamese market. Similar to national business organizations, the international companies interviewed also mentioned policy barriers as their main reason for not expanding their investments in Vietnam. 
Adaptation to climate change Community-Based or Joint Forest Management (as co-benefit of REDD) Forest governance (illegal logging, rule of law, corruption) Poverty alleviation Biodiversity conservation Tenure rights (land, trees) Implementation of REDD+

Implementation of REDD+ strategy, policies and programs (e.g. MRV or safeguards institutions)

Design of sub-national level REDD+ strategies, policies and programs

Design of national level REDD+ strategies, policies and programs

Agricultural land use emission reductions (low emission agriculture/greening business practices, e.g. zero deforestation...

Afforestation and reforestation Sustainable logging practices (RIL; forest certification)

Enhancement of forest carbon stocks (forest restoration /regeneration)

Forest conservation
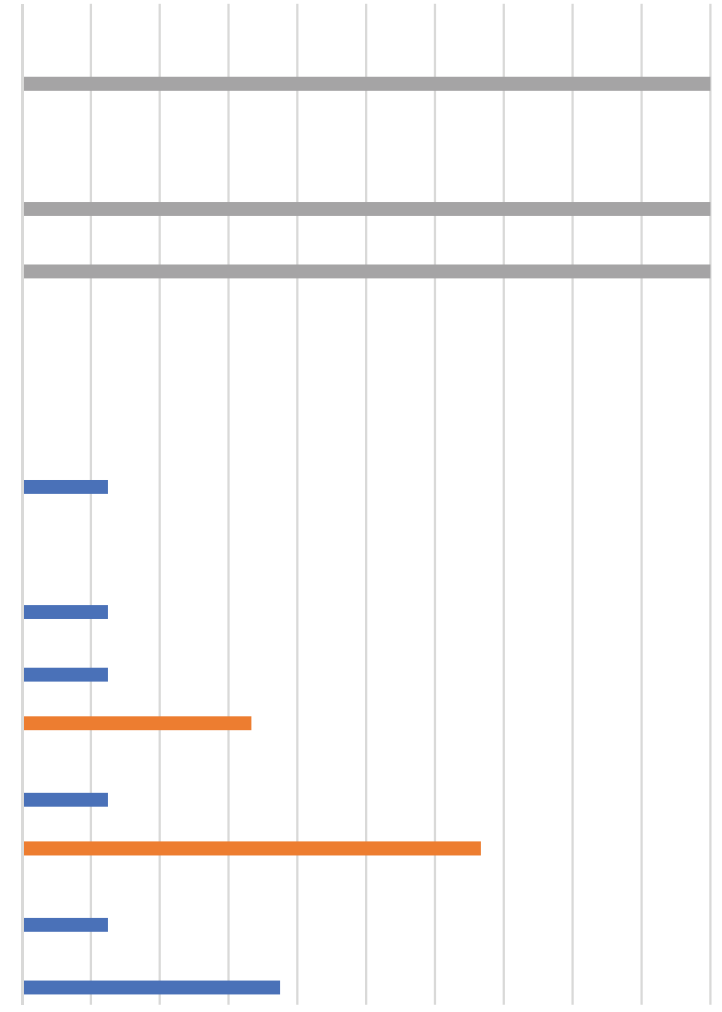

$\begin{array}{lllllllllll}0 \% & 10 \% & 20 \% & 30 \% & 40 \% & 50 \% & 60 \% & 70 \% & 80 \% & 90 \% & 100 \%\end{array}$

$2018-2019(\mathrm{~N}=1) \quad \square 2015-2016(\mathrm{~N}=3) \quad \square 2011-2012(\mathrm{~N}=8)$

Figure 3. Forestry sector priority areas for national business organizations.

Carbon finance/trading

Adaptation to climate change Community-Based or Joint Forest Management (as co-benefit of REDD)

Forest governance (illegal logging, rule of law, corruption)

Poverty alleviation Biodiversity conservation Tenure rights (land, trees) Implementation of REDD+ Implementation of REDD+ strategy, policies and programs (e.g. MRV or safeguards institutions)

Design of sub-national level REDD+ strategies, policies and programs Design of national level REDD+ strategies, policies and programs Agricultural land use emission reductions (low emission agriculture/greening business practices, e.g. zero deforestation...

Afforestation and reforestation

Sustainable logging practices (RIL; forest certification)

Enhancement of forest carbon stocks (forest restoration /regeneration)

Forest conservation

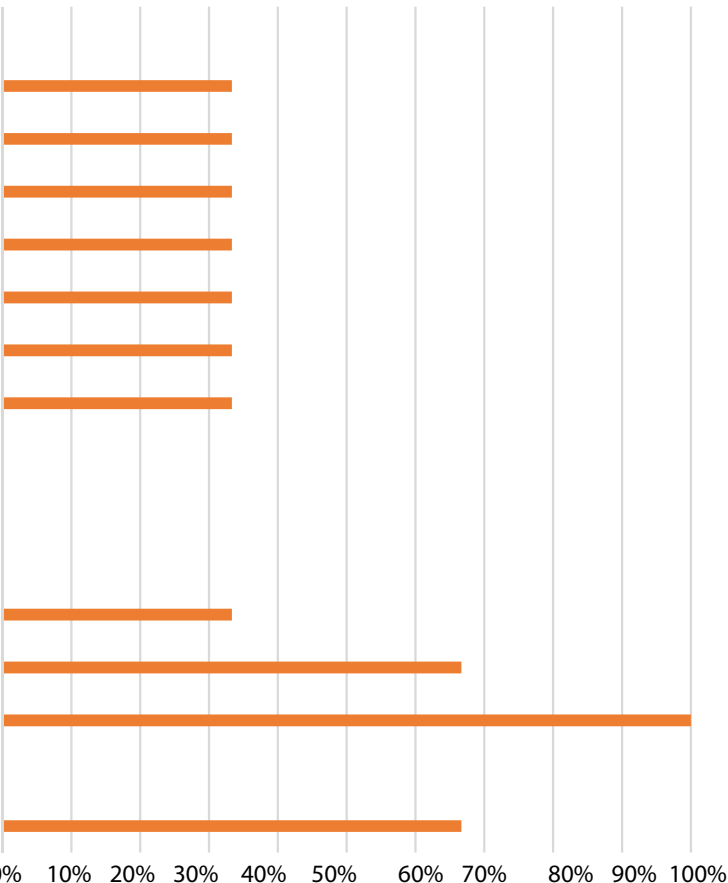

$2018-2019(\mathrm{~N}=0)$

$2015-2016(\mathrm{~N}=3)$

$2011-2012(\mathrm{~N}=0)$

Figure 4. Forestry sector priority areas for international business organizations. 


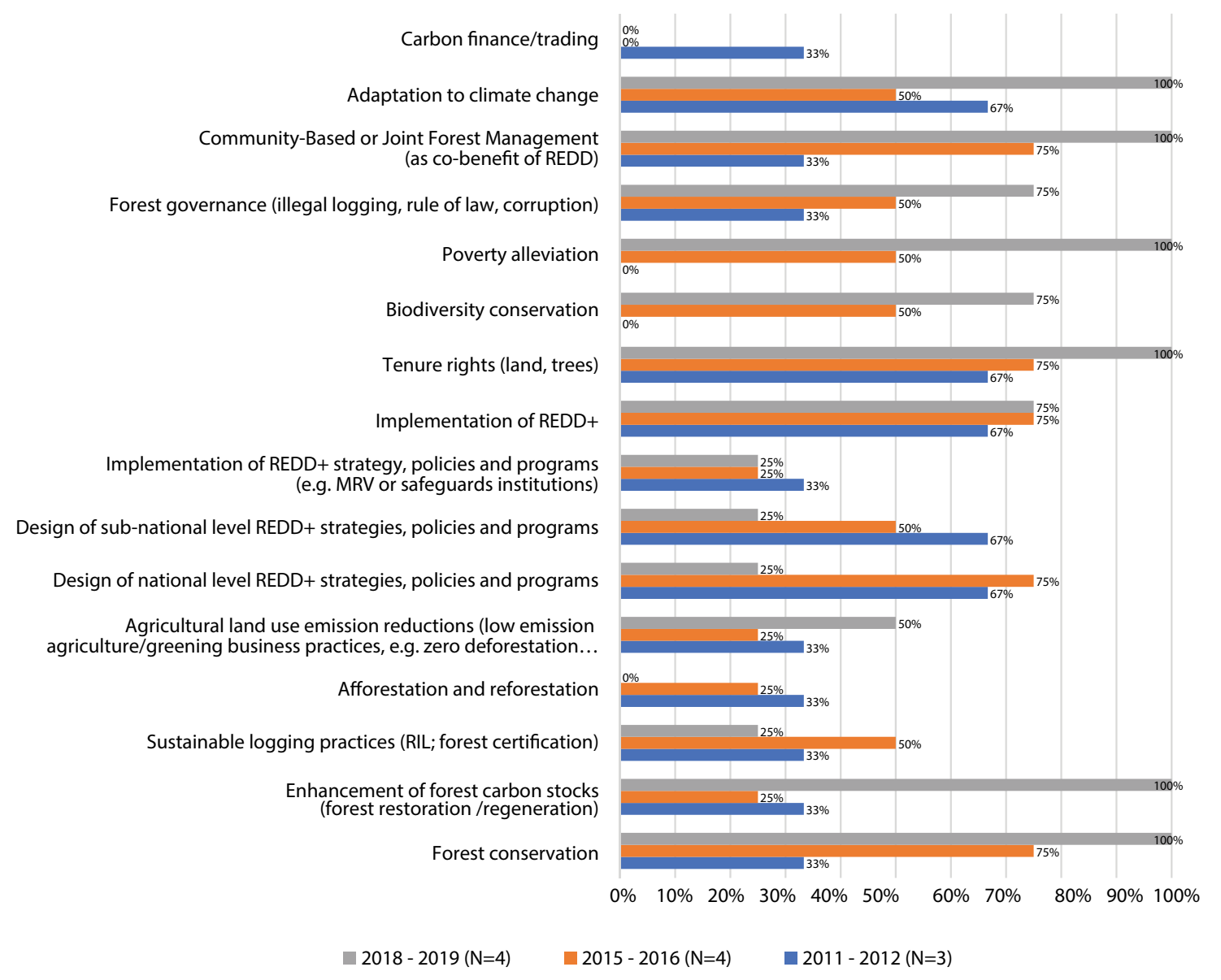

Figure 5. Forestry sector priority areas for domestic NGOs.

\section{Domestic and international non- governmental organizations}

Figure 5 provides an overview of domestic NGOs' changing priorities in forest protection and development. Although areas relating to REDD+, reforestation, sustainable logging practices, and carbon trading have steadily received less attention from domestic NGOs, all other areas are being afforded more attention and investments from this group. Domestic NGO's reduced priority over areas like REDD+ mainly because their projects and programs having expired. However, these organizations' financial resources are growing in other areas, such as climate change adaptation and agricultural land use emission reductions.

Unlike domestic NGOs, over the last ten years, international NGOs have shown concern for all sixteen of the forestry sector areas listed in Table 1. Only two areas: site-level REDD+ pilots and REDD+ implementation, received decreased attention from international NGOs. While domestic NGOs are no longer prioritizing REDD+ due to a lack of financial support, international NGOs are still prioritizing REDD+ activities, particularly supporting REDD+ implementation at the provincial level.

\section{Government agencies}

Figure 7 shows government agencies' investment prioritization and support has increased gradually over time, particularly for: agricultural land use emission reductions; implementation of REDD+ programs; biodiversity conservation; poverty alleviation; forest governance; adaptation to climate change; and carbon finance/trading. Notably, a number of investment priorities fell during the 2015-2016 period: MRV; emissions reduction; and carbon finance, but these had been restored by 2018-2019. On the one hand, increasing interest in certain areas of the forestry sector demonstrates that new international requirements Vietnam is obliged to comply with have led to policymakers setting more priorities. On the other hand, in the context of forestry sector modernization, 


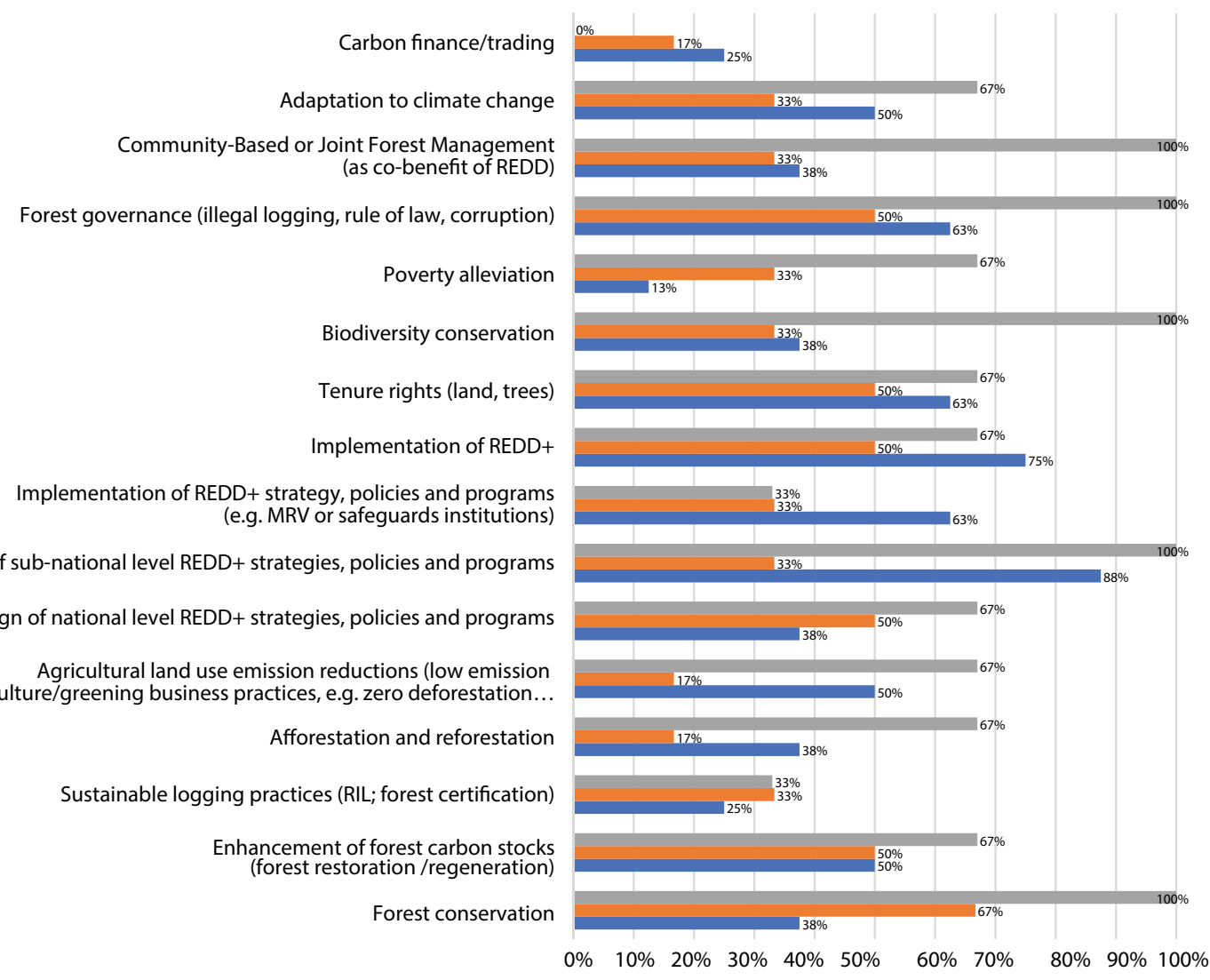

$2018-2019(\mathrm{~N}=3)$

$2015-2016(\mathrm{~N}=6)$

$2011-2012(\mathrm{~N}=8)$

Figure 6. Forestry sector priority areas for international NGOs.

new issues (for example, new sources of financing for industry from carbon payments and services) have had to be removed so that the sector can be developed more expansively.

\section{National and international research institutes}

Over ten years, national research institutes' priorities have focused remarkably more on increasing reserves from reforestation; piloting REDD+ at the provincial and national levels; reducing emissions from agriculture; community-based forest management; adaptation to climate change; and sustainable forest governance (practicing sustainable timber extraction, and preventing deforestation and forest degradation) (see Figure 8). Meanwhile, international research institutes are now prioritizing REDD+ implementation; tenure rights; and enhancement of carbon stocks from forest restoration (see Figure 9). Despite changes in their priorities, both national and international research institutes are conducting research on all issues relating to forest protection and development.

\section{Potential and opportunities}

All fields of forestry development have received more investment interest from different stakeholders - The number of stakeholders considering these sixteen forestry development areas their priorities is increasing. For example, in 2011 , only $37 \%$ of participants interviewed prioritized investment in biodiversity conservation while this number had increased to $72 \%$ in 2019 . Similarly, despite only $33 \%$ of the organizations interviewed in 2011 demonstrating concern for improved forest governance, this figure had risen to $79 \%$ in 2019 . Notably, key forestry areas, such as forest conservation and development, climate change adaptation, and afforestation and reforestation, have received consistent support from different stakeholders throughout the years. Additionally, in 2010-2011, harmonization between forestry development and socioeconomic development objectives received little attention and priority from stakeholders (only $13 \%$ in 2011). However, by $2015-2016$, this had become the concern of $45 \%$ of respondents, and had risen sharply to $69 \%$ by $2018-2019$. A number of forest conservation, 


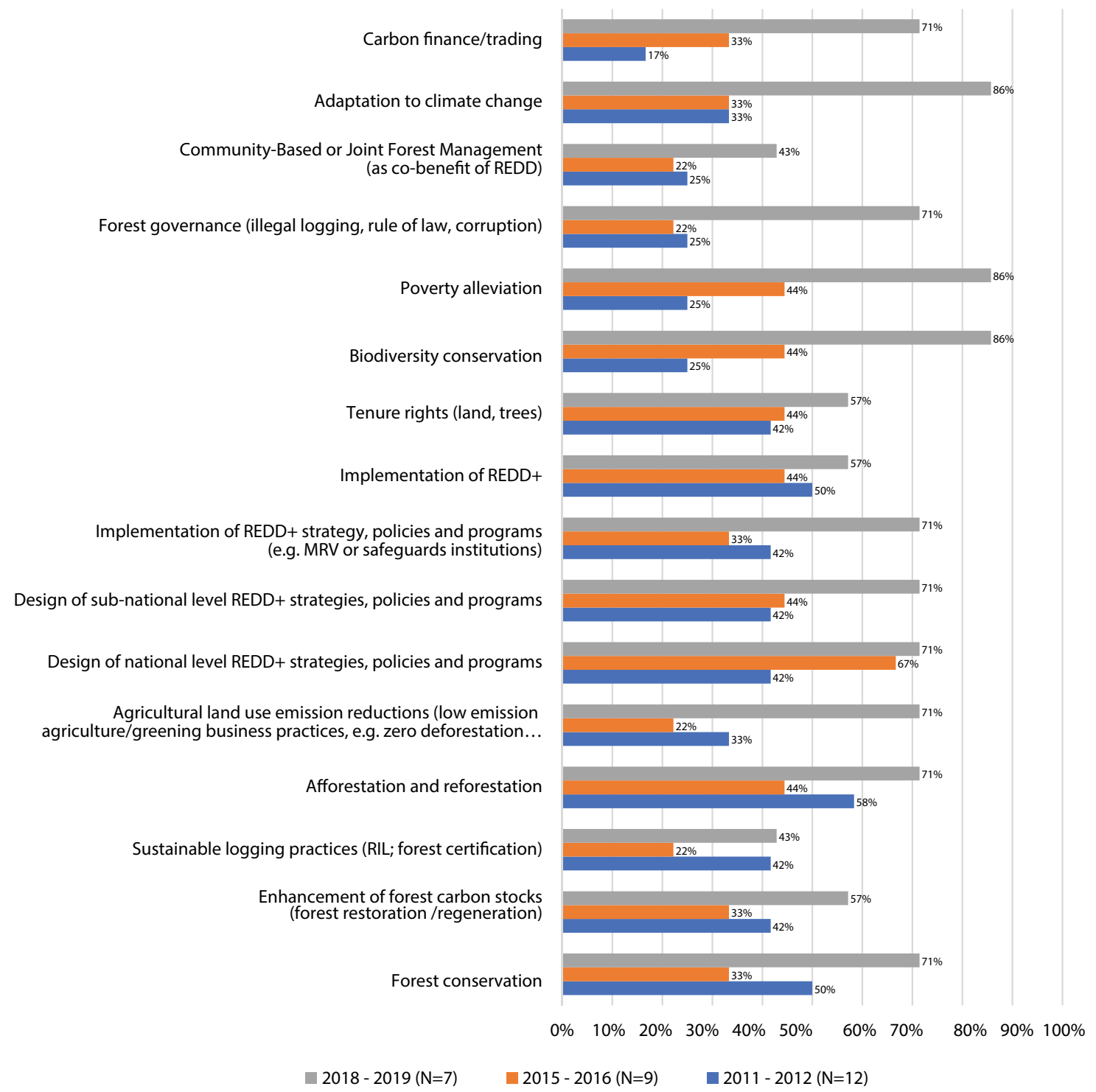

Figure 7. Forestry sector priority areas for government agencies.

protection and development activities have become priorities and secured support from many organizations in Vietnam in order to create favorable conditions for more expansive development of the forestry sector. Concern for forest and biodiversity conservation increased on average from around $50 \%$ in the previous period to approximately $70 \%$ by 2018-2019.

Financial support for new areas - Many areas and initiatives, despite remaining in their pilot phases as new global concepts, have received a lot of stakeholder investment and prioritization. REDD+ and agriculture sector emissions reduction (for example, business sector commitment to reduce deforestation and forest degradation) were the investment priorities of 31\% of stakeholders interviewed in 2011-2012 and 2015-2016, but had become the financial support and investment priorities of $69 \%$ of organizations surveyed in 2018-2019.

\section{Investment gaps and priorities}

Although the prioritization of financial and technological support during the period from 20112019 has created favorable conditions for developing the forestry sector, stakeholders' current priorities also indicate that many areas remain underdeveloped and their investment potential and roles have not been met. 
Adaptation to climate change Community-Based or Joint Forest Management (as co-benefit of REDD)

Forest governance (illegal logging, rule of law, corruption)

Poverty alleviation Biodiversity conservation Tenure rights (land, trees) Implementation of REDD+

Implementation of REDD+ strategy, policies and programs (e.g. MRV or safeguards institutions)

Design of sub-national level REDD+ strategies, policies and programs

Design of national level REDD+ strategies, policies and programs

Agricultural land use emission reductions (low emission agriculture/greening business practices, e.g. zero deforestation...

Afforestation and reforestation

Sustainable logging practices (RIL; forest certification)

Enhancement of forest carbon stocks (forest restoration /regeneration)

Forest conservation

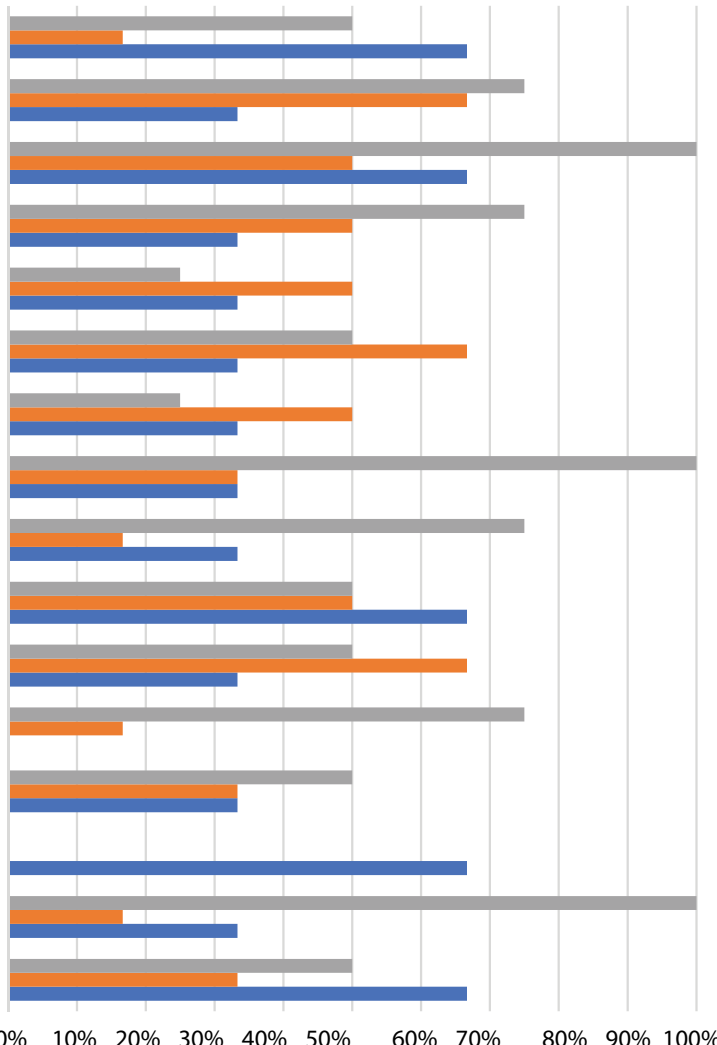

$\begin{array}{lllllll}0 \% & 10 \% & 20 \% & 30 \% & 40 \% & 50 \%\end{array}$

$\square 2018-2019(\mathrm{~N}=4) \quad \square 2015-2016(\mathrm{~N}=6) \quad \square 2011-2012(\mathrm{~N}=3)$

Figure 8. Forestry sector priority areas for national research institutes.

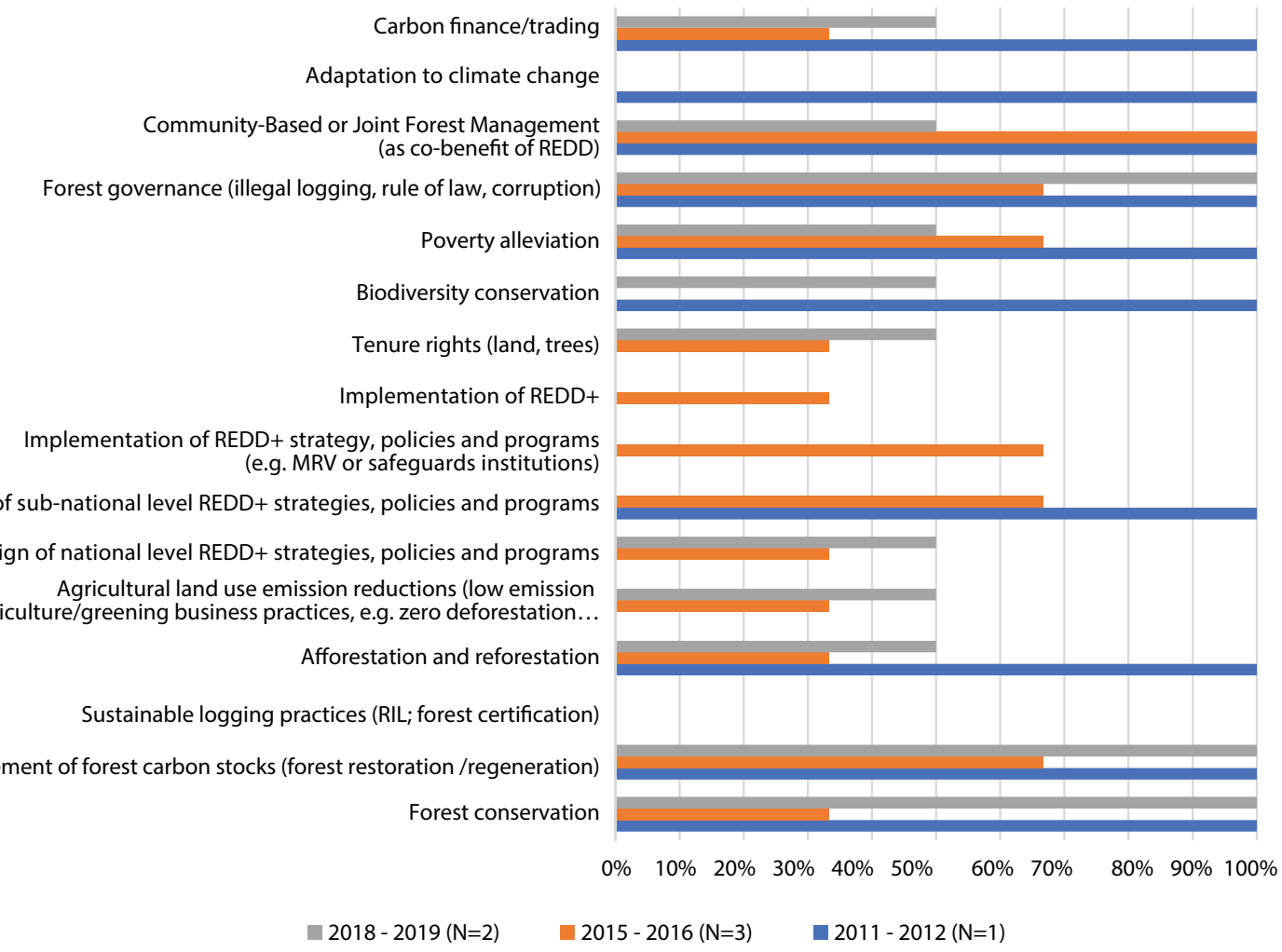

Figure 9. Forestry sector priority areas for international research institutes. 
Carbon finance/trading - International discussions on the role of forests and forestry in the context of climate change are always associated with emissions reduction and carbon trading. However, investment, research, support, and market development for carbon trading in Vietnam concerned only $29 \%$ of the organizations surveyed in 2011-2012, 18\% in 2015-2016, and 45\% in 2018-2019. In the context of Vietnam conducting a pilot policy for carbon payments and services, implementing a national REDD+ program, and fulfilling its greenhouse gas emissions reduction commitments under the Paris Agreement, stakeholders should provide more financial and technical support so Vietnam can implement these policies more effectively.

Support for timber product processing - Wood and timber product processing is one of five programs under Vietnam's Forestry Development Strategy for 2006-2020. However, research results indicate that stakeholders have shown little interest in and support for this field, in disproportion to the roles of the wood processing industry and trade in forest products. The lack of resource support in this area can affect the industry's long-term development, and therefore requires careful consideration.

Support for research in the forestry sector - Though national and international research institutes are conducting research on comprehensive development of this sector, survey results show that other stakeholders have yet to prioritize support for research. The lack of financial and technical support for research will lead to policy decisions not being based on reliable scientific results. As the state budget for scientific research becomes increasingly limited, and research units in the country will eventually have more autonomy to conduct research, technology transfer and financial support from international organizations will provide policymakers with more up-to-date and accurate scientific information.

Some major donors' attention to and prioritization of community forestry is decreasing - Study results also show that some of the major sponsors of community forestry development and implementation are gradually reducing their interest in and prioritization of this area. Achieving the social forestry goals of the Forestry Development Strategy for 2006-2020 and the 2017 Forest Law will require significant attention to this area.

Inadequate support for comprehensive forestry sector development - The aims of the Forest Law are to develop a comprehensive forestry sector, a chain of management, protection, development, forest use, and forest product trade. However, stakeholders' areas of interest and priorities have so far focused mainly on forest management and protection, and research

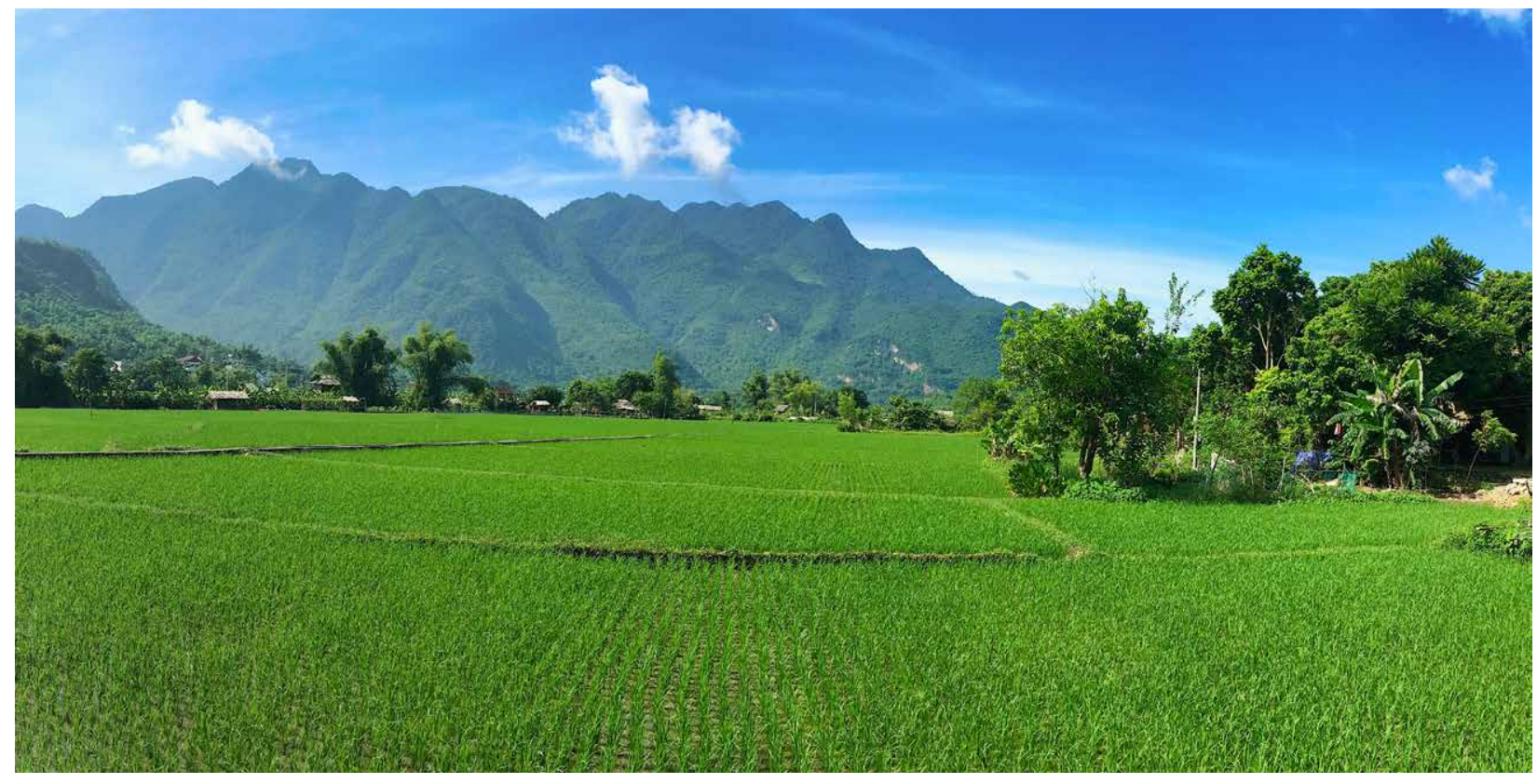

Landscape in Northwest of Vietnam. Taken at Mai Chau District, Hoa Binh Province. Photo by Hoang Tuan Long 
and policy support for REDD+ activities, while other activities have received inadequate attention and support. In regard to forest development, stakeholders are interested in afforestation and reforestation, yet many other areas, such as developing high quality forest seed; improving forest productivity and quality; planting large timber species; agroforestry; and joint ventures involving households, businesses and the private sector to develop plantations have garnered insufficient interest. In terms of forest use, new priorities for sustainable forest management (e.g. forest certification) have left areas such as NTFP development, forestry services, and ecotourism almost devoid of interest. In addition, while modernizing the forestry sector is an essential requirement, and in line with the global trend, little attention has been paid to the application of science and technology in forestry.

It will be vital to study trends in sources for forestry finance in the coming years. It will also be essential to develop mechanisms, policies and legal corridors to implement regulations in accordance with global trends.

\section{Conclusion}

This policy brief demonstrates that stakeholders' investment priorities in forest protection and development are expanding to keep pace with forestry sector development trends worldwide. Favorable support from different stakeholders will create advantageous conditions for Vietnam to experiment with and pioneer many policy areas and new technologies. Areas such as poverty alleviation, forest governance, biodiversity conservation, agricultural land use emission reductions, and sustainable logging practices, as well as REDD+ design and implementation have attracted the greatest interest from stakeholders. Issues of tenure rights and sustainable forest extraction, despite witnessing limited increases in interest, remain investment priorities of the majority of key organizations surveyed. Stakeholders' prioritization of and investment in afforestation and reforestation have decreased over time. Although the prioritization of financial and technological support during the period from 2011-2019 has created favorable conditions for developing the forestry sector, stakeholders' current priorities also show that many areas remain underdeveloped, and their investment potential and roles have not been met. As each stakeholder requires different investment priorities, understanding these can not only help the Government to use resources more efficiently and avoid duplication, but also create more effective strategies for mobilizing capital for the forestry sector.

\section{Acknowledgement}

This study is a component of the Global Comparative Study on REDD+ being conducted by CIFOR (www. cifor.org/gcs). We would like to thank donors including the Norwegian Agency for Development Cooperation (NORAD), United States Agency for International Development (USAID), and the CGIAR Research Program on Forests, Trees and Agroforestry (FTA) for their financial support for this study. 